\title{
JURIDICAL AND INSTITUTIONAL ASPECTS OF THE EUROPEAN REGIONAL COMMUNITIES
}

\author{
PAUL ReUTeR*
}

I

\section{General Characteristics of the Three Communities}

\section{A. Economic and Political Characteristics}

Three Communities form the subject of this study-namely, (a) the European Coal and Steel Community (E.C.S.C.), (b) the European Economic Community (E.E.C.), and (c) the European Atomic Energy Community (Euratom). All three are regional international organizations, economic in character. Their object is to unify the economies of the member countries by creating among them a common market-in one case for coal and steel (E.C.S.C.); in another case for the products and substances relating to nuclear energy (Euratom); and finally, for the generality of the bases and products of economic life (E.E.C.). At the heart of these enterprises, there is a common economic philosophy that can be defined by the concept of regulated competition or institutional markets. By this it must be understood that the economic regime of these unified areas entails two combined elements - on the one hand, competition and, on the other, an organization charged with the duty of elaborating and applying rules, supervising their application, and fixing penalties for their violation. Naturally, this characteristic of organization varies with the products and the circumstances involved. Thus, it is very marked for the fissionable materials and minerals subject to the control of the Agency created by the Euratom treaty. ${ }^{1}$ The characteristic is almost equally visible with respect to coal and steel in the event of a grave economic crisis and, even in a normal period, includes strict rules about publicity and nondiscrimination with respect to coal and steel. ${ }^{2}$ As for the E.E.C., although the organization of the market can be rigorous with respect to agricultural products, ${ }^{3}$ it is fairly light for the bulk of other products subject to the Treaty and tends toward antitrust legislation of the American type.

Against this backdrop one is better prepared for a technical analysis of the powers which have given the European Regional Communities their juridical importance. These powers were not intended merely for the supervision of a completely private and liberal economic movement, but instead for the performance of a more active governmental role. The powers delegated to the Communities, such as legislation,

- Professor in the Faculty of Law and Economic Sciences of Paris; jurisconsult-adjoint to the French Ministry of Foreign Affairs.

${ }^{2}$ Euratom Treaty arts. 52-76.

2 E.C.S.C. Treaty arts. $71-75$.

${ }^{8}$ E.E.C. Treaty arts. $38-47$. 
jurisdiction over individuals, and imposition of penalties on enterprises, are not those generally delegated by countries to international organizations. From this delegation the Communities derive great political importance.

It must be added that the States concerned in the three Communities have considered that their creation would open the way towards the political unification of Europe. This intention was clearly expressed in the Schuman declaration of May 9, $195^{\circ}$ and in the preamble to the E.C.S.C. Treaty; and it is also demonstrated by the attempt to create a European Defense Community in the Treaty of May 27, 1952. But, when the Defense Community, as well as its projected extension into a political community, never saw the light of day, the authors of the Rome treaties of 1957 constructed the E.E.C. and Euratom in such a way as to mask their political importance and to foster the illusion that, in the modern world, economic unification could operate while leaving national sovereignty intact. Even if there is a possibility of doing this while the object is limited to partial economic unification along the lines of the E.C.S.C. and Euratom, it becomes less likely in the framework of the general common market.

Nonetheless, the ambiguity of the Rome Treaties (Euratom and E.E.C.) is real. Not only is there visible an opposition between the exterior presentation and the real strength of certain institutions, but-what is even more serious-these agreements include a large number of matters left undetermined, especially in the case of E.E.C. In fact, with respect to E.C.S.C. and, to a lesser extent, Euratom, the Member States could set forth in the very text of the signed agreements the essentials of the rules to be applied. Such was not true as to the E.E.C. because of the wide range of the subject matter. The agreement creating E.E.C. contains certain relatively precise rules on some points (such as the timing for disappearance of customs and quantitative restrictions); but, as for the rest, it contains only principles and promises. What appears is the framework for a treaty! On the other hand, the real form of E.E.C. is still not determined; and to make concrete the principles put forward in the treaty depends upon the constancy of the political determinations made by the Member States.

These remarks tend to caution the jurist to prudence in drawing general conclusions. The political scientist makes the inventory of the forces working for the unification of Europe and of the obstacles encountered by those forces. The jurist can only point out what is certain, what is doubtul, and by what paths evolution is possible.

\section{B. Institutional Framework of the Communities}

In a general way, the three Communities show the same over-all framework for their institutions-namely, a two-headed Executive, a parliamentary assembly, and a Court of Justice. In each Community the executive power reposes in two groupson the one hand, a body of independent persons nominated in common accord by the Member States but acting outside the scope of national influences, and, on the other 
hand, a council of national ministers, who take part, subject to varying conditions, in deliberations which, more or less and according to the particular case, bind governments and private enterprises. These two groups collaborate in governing each of the Communities. The Council of National Ministers corresponds to the central organ of all international organizations; by contrast, the body composed of independent persons is a relative innovation. No doubt, in all international organizations-and in the political life of all countries ${ }^{4}$-there are groups of independent individuals which, within the organizational framework, have the authority to offer proposals for action by the organization or to exercise quasi-judicial functions. However, an especially significant feature of the independent executive organs created for the three Communities-E.C.S.C.'s High Authority and the Commissions of E.E.C. and of Euratom-is that they foreshadow a European parliamentary regime, since the members of these organs, though originally government nominees, are politically responsible to a European assembly. In fact, however, the membership of: those bodies has been made up not only of politicians but also of experts.

The European Parliamentary Assembly, which has authority to act within theframework of each Community, has so far been constituted only of delegates selected. by the respective national assemblies from their own membership. However, the treaties anticipate that Assembly members may be elected by direct universal suffrage; and a project recently approved by the Assembly concerns making this prospect a reality.

The Court of Justice, which is open not only to Member States but also to privateenterprises and, in a certain measure, to the organs of the three Communities, has a. complex role to play, the most important part of which is the control of the acts of the executive organs of the Communities. This control is exercised through the: procedure for annulment of a decision made by the Executive.

\section{Relations Between the Communities}

In light of the similarities in the general institutional frameworks of the European: Communities, the question suggests itself: Is the time not ripe to merge the three Communities? In connection with this important question, one notes that juridically, each Community has a distinct and precise basis; the international agreements relating to them are formally distinct for each Community. The explanation for this. is obvious in the case of the E.C.S.C., which stood alone at the outset in 1952. Then,. in 1957, the negotiators at Rome took enormous care to ensure that each of the two. new Communities should rest upon its own juridical instruments. Even so, the three Communities have numerous and delicate relationships-a great number of which are poorly defined.

For one thing, the Rome agreements sought to avoid a disorderly multiplication. of organs; and, in a special Convention it was agxeed that certain organs would be common to all three Communities (Assembly and Court of Justice), or to two of

\footnotetext{
4E.g., regulatory commissions, such as the Federal Trade Commission in the United States.
} 
them (Economic and Social Committee). This solution has been extended without formal agreement to other new organs (Secretariat of the Council of Ministers and the Information Services). It constitutes a new and original adaptation of an institution-union of personnel-well known to public law. This device can render great service; but at the same time it creates considerable juridical difficulties, many of which have not yet been resolved. Carried too far, these measures for union of personnel might result in the complete suppression of the organic independence of each Community. In this same vein, suggestions are made daily for unifying in one body the E.C.S.C.'s High Authority and the Commissions of E.E.C. and Euratom; but realization of such proposals is far from simple.

In connection with efforts to harmonize and unify the three Communities, juridical hurdles must often be surmounted. To cite only one example, the national governments are still competent under the E.C.S.C. Treaty to negotiate commercial agreements relating to coal and steel; but when the provisions of articles IIO-II6 of the E.E.C. Treaty are applied, they will not be authorized to negotiate such agreements as to other products. Moreover, the E.E.C. Treaty contains a monetary clause safeguarding the free circulation of all the products which it governs, but the E.C.S.C. Treaty lacks such a clause. Should it then be concluded that the provisions of the E.E.C. Treaty (lex generalis) apply where the E.C.S.C. Treaty (lex specialis) is silent? Such an effect can be doubted, since this question is too complex to permit its solution by so summary a formula.

What can be said without danger of error is that the working out of the Treaty establishing the E.E.C. will be necessarily accompanied by a unification of the three Communities; but that result will be neither immediate nor complete, and the methods employed may be diverse.

\section{Conclusion}

In concluding this section of the paper, the dynamic character of the Communities must be stressed. They are built to an economic plan, and with an implicit political objective. They are equipped with four main organs (Council of Ministers, body of independent executives, Court of Justice, and Parliamentary Assembly), and that may well lead to the pre-eminence of one or the other of those organs. Further, though separate in their juridical foundations and in their respective personalities, the three Communities nevertheless tend to become unified.

These wide possibilities of evolution raise a fundamental question which encompasses all the others. To what extent do the European Communities establish a European federalism? Or, to use an adjective which has already given rise in Europe to passionate controversy, to what extent are the European Communities supranational? The question must be posed in these terms because public opinion so poses it; but it must be stressed that, from the scientific point of view, such questions use a vocabulary which may engender considerable confusion. Although it will be seen in the course of this study that the European Communities display 
certain very pronounced federal aspects, it would be wrong to adopt any rigid notion of federalism with respect to them. There is no absolute distinction between federal and international structures, and there are numerous varieties of federalism. The federalism of the United States today is not the same as it was in the time of Chief Justice Marshall; that of India does not resemble that of Canada; and it may well be questioned whether, in a more general way, the technical evolution of the modern world, the mode of evolution of military problems, economic relationships, and transport will not lead to extensive regrouping of States in the second half of the twentieth century on the basis of formulae very different from those of the nineteenth century and the early part of the twentieth.

Two important characteristics enable one to fix the degree and the nature of the federation of all political structures: the equilibrium of political forces and the relationships affecting the juridical organisms. Indeed, in its most general form, the spirit of federalism is simple. It relies upon equilibrium between the federaI and the local powers; and in the sphere of juridical technique it leads to a harmonious system of relationships between the federal and local laws-a system which transposes political equilibrium to the juridical sphere. It is from these points of view that the Communities should be studied in order to determine what evolution may take place from the initial steps traced by the Treaties.

\section{II}

\section{The Equirtbrium of Political Forces}

The situation at the outset is simple to describe. There were no European political forces but only national states, national political parties, and national enterprises. The founders of the E.C.S.C. wished to create European forces by an interplay of institutions. Although the organs of the E.C.S.C. do not all exhibit to the same degree the aptitude to represent and evolve a European political force, it is possiblestarting with the E.C.S.C. Treaty and examining at the same time the structure, relationships and powers of its organs-to discern an initial plan. It will then be shown how this plan has evolved and what transformations have been achieved by the Treaties of Rome and subsequent events.

In the E.C.S.C. Treaty the central governmental organ is the High Authority, which is placed under the ultimate control of the Court of Justice. The advantage accruing to the European forces from this arrangement is considerable, since the High Authority and the Court are absolutely independent of the national governments. Although their members are nominated by the governments, it is for a relatively long period of six years, and, at least in the case of the High Authority, a principle of co-option by the members first designated by the States arises in combination with that of governmental designation in such a way as to reinforce still further the independence of the members. The character of the Assembly was not fixed at the outset; since it is made up of delegates chosen by the component national 
parliaments, its role will move in different directions according to the influence of the European or nationalistic tendencies which will appear in the Assembly.

Contrariwise, the Council of Ministers would appear essentially to represent the national governments. However, its role is secondary because it is to intervene only in limited cases-either by giving conforming advice when confronted with certain important decisions of the High Authority (i.e., advice which must be favorable if effect is to be given to the decisions), or by itself making certain decisions relating to the administration of the Community. Thus, at least in principle, the Council can function as a federal organism without being impeded by the unanimity rule which so often paralyzes international organizations.

A first general impression would support the view that the Paris Treaty of $195 \mathrm{r}$ Thas accorded a very important place to organs by means of which European political forces can gain expression. Nevertheless, other considerations point in a different direction. In the first place, the Treaty itself has set out a very important part of the rules which are to be applied in the Community. To this extent, the functions of the High Authority are limited to the application of these rules and the control of their operation without the assumption of real political responsibilities. The conclusions which can be drawn from the structure of the E.C.S.C. must, therefore, not Be exaggerated. This observation is all the weightier since the sphere of the powers of the E.C.S.C. is limited with precision. Reference can undoubtedly be made to powers transferred exclusively to the E.C.S.C.-for example, in regard to the prices rof coal and steel-payable to the producers. However, besides these powers of the Community, there exist certain powers exercisable by the Member States in competition with the Community; and there are many such powers affecting coal and steel. Some of these powers are governed by the Treaty, while others are subject to an obligation, rather badly defined, to ensure harmony. It would be quite erroneous to believe that coal and steel come within the powers of the Community; such a formula is almost void of meaning. What should be said is that as regards coal and steel the Community exercises precise and limited powers.

Finally, it must be noted that, even for the independent organs, a weighting effect arising from national political influences has intervened with respect to the designation of members. Thus, the figure of nine members fixed for the High Authority is the result of a series of minute considerations relating to national influences, ${ }^{5}$ and the designations of members for the Court of Justice have likewise been forced to bear those considerations in mind. Furthermore, the impossibility of reaching agreement as to the permanent headquarters of the institutions-an impossibility which to this day has not yet been overcome-shows at the outset the force of national resistances to unification.

'It was, of course, necessary that each State have at least one national among the members of the High Authority. It was, moreover, necessary that the total number be uneven. A seven-member authority would have led to the presence of two German or two French members-a prospect to which neither country would have agreed. A nine-member authority composed of two German, two French, four Benelux (Belgium, the Netherlands, and Luxembourg) and one Italian member was found amenable, and therefore adopted. 
Such being the initial situation, how far has experience allowed these diverse forces confronting one another to find their equilibrium? Any general evaluation in this regard must be very shadowy. It should take account of factors external to the Communities and notably of the general political and economic situation. The first years (1952-53) were marked by the expectation of a reinforcement of the E.C.S.C. by new treaties. Then the rejection of the European Defense Community, together with the opposition of Mr. Mendè-France (1954-55), considerably slowed down the affirmative recognition of European political forces. These revived, however, after the conference of Messina (June 1955) and the conclusion of the Rome agreements (March 25, I957). The general economic situation was very favorable to the E.C.S.C. until 1958; but since that date the coal crisis has imposed a heavy burden on that Community, and at the same time the E.C.S.C. has had to face the most difficult problems which it had not been able or willing to resolve earlier-such as the elimination of discriminations in transport and reform of the selling and buying organizations relating to coal. Meanwhile, from 1958 to 1960 , the new Communities, particularly the E.E.C., were making brilliant opening advances, which placed the E.C.S.C. somewhat in the shade.

The powers of the High Authority have proved to be less than was foreseen in the provisions of the Treaty. The members of the High Authority, being at the same time both European functionaries and men of politics, when faced by the national forces which they had to encounter, have not been able to affirm their responsibility and to demonstrate their political energy. These members seem to have been profoundly divided among themselves and more anxious to use the provisions of the Treaty to avoid assuming responsibility, than to reach fixed objectives. These causes of internal weakness are inevitable when it is realized that the members of this body are not recruited in accord with any political affinity which could and should bind a team called to undertake so heavy a task, but in accord with the play of national politics in the six countries concerned. To these causes of weakness has been added a deliberate determination on the part of the national governments to cease making new concessions to the E.C.S.C.

In practice, the special Council of National Ministers has shown the reality of its power. Actually, the national Ministers themselves are not the sole depositaries of this power. Their episodic meetings and the changes of membership resulting from events of national political life prevent them from bearing exclusively the weight of the functions granted them by the Treaty. However, the permanent national functionaries, who from the national standpoint oversee the relationships between the Community and the national States, have experienced a growth of their importance over the whole of this period. They are the people who prepare for the regular meetings of the Council; and they are to institute on the European plane a coordinating committee, whose meetings are to form the effective base for concerted activity.

From the outset the Assembly has established itself as a parliamentary organ 
and has sought to extend its powers; ${ }^{6}$ it has claimed the honor of being the most active instrument in the progress of European unification. With a view to constituting homogeneous European political forces, the national delegates at this Assembly have established groups based on ideological affinities without regard to nationality. This initiative has been hailed-and rightly so-as a step in the development of European federation; but even here it is necessary to preserve a fairly balanced view of the development of European institutions. The Assembly as a protagonist of European unification has seen its role made easier by the fact that the political forces hostile to that unification have not been represented among its members ${ }^{7}$ and that, up to the present, absolutely vital interests have not been at issue in the E.C.S.C. ${ }^{8}$ Otherwise, the Assembly has scarcely any influence upon the national governments who are responsible for the delay in unification, nor even upon the Council of Ministers. Its debates up to the present time have had no direct important repercussions on the national parliaments.

As for the Court of Justice, its functioning in the framework of the E.C.S.C. has confirmed the lessons of federalism. In its jurisprudence it has defended the supranational character of the High Authority-sometimes, but rarely, annulling the decisions of that Authority when it appeared that the Authority had made too wide concessions under pressure from national politics.

Contrary to what has often been said on this subject, the Rome arrangements have confirmed, rather than modified, the experience of the E.C.S.C. Since 1958, the number of members of the Assembly is double what it was under the E.C.S.C.; but its role and its attitude have not changed. The Court of Justice has still not had to pronounce any important judgment relating to the application of the new Treaties, but there is no reason to consider that tendencies it has already displayed will change.

The most profound modification, it is well known, concerns the respective roles and the relationships of the independent executive and the Council of Ministers, the executive having in the Rome agreements changed its name from "High Authority" to the less colorful one of "Commission." Appearances appear to confirm an effacement of the organ most typically European-namely, the Commission. Besides the very significant change of name, it is noteworthy that the members of the E.E.C. and Euratom Commissions are nominated for four years only, and that co-option has

\footnotetext{
${ }^{6}$ The confident spirit of the Assembly best appears in M. P. Wigny, The Parianintary Assemply IN THE EUROPE of THE Six (1958). For a more detached view, see Stein, The European Parliamentary Assembly-Techniques of Emerging Political Control, 13 International Organization 232 (1959). The same movement has tried to manifest itself, but unsuccessfully, in relation to the Assembly of the Union of Western Europe. See Haas \& Merkl, Parliamentarians Against Ministers-The Case of Western European Union, I4 id. 37 (1960).

7 The Communist Party is not represented in the Assembly, a fact which appreciably affects the composition of the French and Italian delegations.

${ }^{8}$ It was perhaps different when the coal crisis was discussed in I959 at the European Parliamentary Assembly; but, when the Assembly wanted to throw the responsibility for a difficult situation back to the Council of Ministers, its resolution received only 44 votes out of 142 . Resolution of April $x 6$, I959, [1959] Journal Officiel de la Communauté Européenne du Charbon et de L'Acier 56o [hercinafter cited as Journal OFFICIEL].
} 
disappeared. Further, the most important powers are vested in the Council and not in the Commission. The Commission's role, apart from secondary methods of execution, appears on the surface to have been reduced to a simple right to make proposals to the Council of Ministers; the Council makes the decisions. Such are the appearances, but they are largely deceiving.

Actually, the proposals of the Commission have an important juridical effect. In the majority of cases the Council has the right to adopt the proposals of the Commission by a qualified majority or to reject them, whereas a decision contrary to those proposals requires a unanimous vote. In this way the Rome agreements have led the way to a veritable political impasse. Unless the Council can achieve unanimity within its own body, all it can do is to accept the views of the Commission, or leave the problem unsolved. In practice, the Commission prepares its proposal for action along lines indicated by the course of debates within the Council, with whose members the Commission has had indirect contact in advance. Moreover, there are common meetings between the Commission and the Council. If the first proposal of the Commission is rejected, the Commission sometimes presents another in the course of the same meeting in order to achieve a result-with the possibility of reverting to the first proposal if the second one also meets with rejection. In reality, the Commission is an organ of mediation in the national conflicts which break out within the Council; and in this way it can play an extremely important role.

Doubtless, it will be said that this system is very imperfect since the result may be that no decision at all is taken. This is quite true, as unfortunate examples have already revealed. However, it must be pointed out that in the E.E.C. the problem is quite different from that confronted in the E.C.S.C. In the E.E.C. it is a question of arriving at decisions, each of which is the equivalent of what the E.C.S.C. Treaty has stipulated in its economic provisions. It cannot be too often repeated that the E.E.C. Treaty is a framework, a carte blanche, which for the generality of matters considered is confined to announcing general principles, while remanding to Community decisions the task of applying those principles. Instead of concluding twenty or more treaties of the E.C.S.C. type, the Member States have evolved this new mechanism-which certainly has imperfections, but is manifestly more progressive than repeated international conferences of the traditional type, each leading to the conclusion of a treaty submitted for ratification pursuant to national constitutional procedures. Each of these decisions can, and undoubtedly will, take into account the competency of the Commission to execute them in the same conditions as those which apply when the High Authority effectuates its own decisions, at least in certain well-determined cases. A part of the objection still remains, since the execution of the E.E.C. Treaty depends finally on the good will-the European will-of the Member States. But does this circumstance astonish anyone? Starting from zero, a federal political force cannot be created in a day.

It may be suggested that, up to the present, Member States have not given proof of a desire for political unification and have not fulfilled the subscribed commitments. 
Attempts could also be made to show that the established rules have not been respected as to coal $^{9}$ and transportation. ${ }^{10}$ Thus, it could be established that the persistence of national positions founded on economic and geographical realities is sufficiently permanent to raise doubt that these positions will be easily abandoned. Economic unification and the realization of a common market, since they cannot be accomplished solely by recourse to such simple measures as the abolition of customs and other quantitative restrictions, presuppose common action in varied and extensive fields; and the States do not show any wild enthusiasm to venture upon the route towards such common action. The whole regime governing coal and the atom needs to be recast to embody an energetic policy; and the decisive test of the vitality of the E.E.C. has not yet been undergone. This test will occur in the adoption of the more specific measures and institutions required for a common agricultural policy.

However, exaggeration in whatever form must be avoided, and a pessimistic conclusion concerning European political forces would not be realistic. The policies and decisions resolved upon by national governments are not arbitrary; they reflect social realities impinging upon those governments. ${ }^{11}$ While social realities and social institutions may not be in complete harmony, there cannot be a complete discord between them. Have, then, the institutions of the Communities permitted, in the broad sense, the development of European political forces? If the reply is in the affirmative, it must be anticipated that these forces, as they gain strength and develop, will, in turn, induce the further development of the institutions. To the present writer, it seems clear that the treaties establishing the three European Communities have given rise, with short delays, to relatively important European political forces. European parties are seen in outline; labor unions in various countries must coordinate their action; business enterprises become Europeanized-all this without taking into account the development of a vast European bureaucracy composed of experts, officials, economists, and jurists. ${ }^{12}$

${ }^{\circ}$ At the present time, not all the States permit the free circulation' of coal coming from third party countries; former organizations of sale and purchase continue to function; and the Belgian market has been isolated from the rest of the common market on the initiative of the High Authority itself. It has been argued that these measures were contrary to the Treaty; and this is so under one interpretation of the Treaty. If this interpretation were to be accepted as valid, it would be necessary to conclude that the draftsmen of the Treaty committed a fundamental economic error. In our view, the Europenn market for coal cannot function unless it is strictly organized.

${ }^{10}$ The harmonization of the conditions of transport laid down in the E.C.S.C. Treaty (Convention Containing the Transitional Provisions $\S$ ro) has never been realized. The provisions are quite insufficient and the anodyne provided by article 79 of the E.E.C. Treaty concerning the climination -of discriminations has not yet been applied (because of the absence of a majority vote by the Council of Ministers).

${ }^{11}$ It is not possible to accelerate without limit the process of unification; neither can that process be stopped on grounds of pure ideology, since it is already a fait accompli. The French Government, after the elections of 1958, was not in favor of the European Communities; the present Prime Minister has - often opposed their development. In spite of this, the movement has continued. The French Government has not only insisted on executing the Treaties, but in fact it has desired to go beyond that and has often submitted itself to the Commission and to action by the Commission. This extremely curious political phenomenon arises quite simply from the pronounced need of every government -destined to last to accept a certain number of realities. European solidarity is not the fruit of a free decision by governments.

${ }^{19}$ This typically European political force marks its strength by having compiled a statute guarantecing 
Yet, if these phenomena (which in the final analysis involve only a fairly limited number of persons) are alone considered, the insight into the development of European political forces and the birth of federalism would be quite incomplete. It is wrong to imagine that Europe is a super-structure attracting to itself ever more numerous elements which will, at a given moment, counterbalance national structure in a really federal equilibrium. Actually, if Europe is to become a meaningful entity, there must be established conditions for a veritable intellectual, social, and juridical harmony which can overcome the obstacles to the development of a common conscience. It serves no purpose to superimpose the action of 5,000 officials and 300 European politicians upon the millions of national officials and national politicians if the latter preserve a strictly national mentality. The functioning of the three Communities has already permitted to a perceptible degree the transformation of the habitual psychological perspectives of the national officials and politicians. Although it is difficult to assess the extent of that evolution, its existence has been made evident by the breadth of the contacts and exchanges between the Communities and the national governments. This situation is the outcome of a state of affairs which cannot be disputed-namely, that solely by reason of their central location at the crossroads of six national influences, the Community organs are better informed and technically better equipped to resolve many problems posed in a purely national framework. If power has a centralizing influence, the converse is no less true, since the fact of being at the center gives more power. In this respect Community institutions play their role. By the fact of their existence and the still rudimentary powers which they exercise, they have impelled the national forces to take part in a contest which slowly transforms the purely national bases of social life.

These observations are not intended to minimize the important problem of the structure of the Communities in relation to that of the Member States; but it suggests a more serene consideration of that problem. In practice, the question is to determine to what extent the administration of the Communities is to be direct or indirect. A recent example can be cited with respect to the rules of non-discrimination in transport. ${ }^{13}$ Should only the national governments and the national tribunals be charged with the application of these rules (in which case one is confronted with a regime of indirect administration), or should certain powers be given directly to European institutions (controlling agencies, Commissions and Court of Justice)? In discussing this problem at the Council of Ministers, the Member States have shown hesitancy in this matter; but the sheer logic of the system requires acceptance up to a certain point of direct intervention by European authorities. Indeed, each State which has accepted European rules will fear that these rules may be twisted or poorly applied if national authorities alone are entrusted with their administration; and so,

European officials against all national influences. Each government ends by consenting thereto, although with regret, under fear of the influence of the neighboring State.

${ }^{13}$ E.E.C. Treaty art. 79. 
to avoid a greater evil, the State will itself submit to control. The real problem will be to fix the degree and the limits of this partially direct administration. ${ }^{14}$

In light of the previous discussion, certain conclusions can now be stated. At present it would be an extreme exaggeration to speak of an equilibrium between European and national forces, since the latter have by far the upper hand in all spheres; $;^{15}$ and it would be an abuse of language to speak of federalism in any strict sense with respect to Europe and the Communities. However, by their structure and by the approach to problems which they compel, the Community institutions tend to develop the social reality of Europe; and, thanks to them, it is possible to perceive the development of European forces which someday perhaps will be able to work in equilibrium with national forces.

\section{III}

\section{Community Law and National Law}

In the general political sphere, the Communities display the beginnings, fragile as yet, of federalism; in the juridical sphere an analogous statement may be madebut with a difference. Although still very imperfect, the juridical construction of European federalism shows advances over the political. This is not surprising, for in the general evolution of federalism the establishment of juridical rules always precedes the creation of specific organs charged with application of those rules. The situation of the present international community as a political system is the most striking demonstration of this fact. Most of the rules of international law already show a certain consistency; and yet the international community does not really possess the differentiating organs which would give it an autonomous structure nor does it rest upon powerful political forces.

The European Communities, which suffer by reliance on political forces less strong than national forces, do not themselves possess any power of restraint. ${ }^{16}$ Nevertheless, a Community juridical system-relatively diverse, coherent, and fortified by a well-developed judiciary-grows in strength from day to day. Both the legislative and judicial functions are exercised in the European Communities in a much more perfect form than in the international community; and European Com-

\footnotetext{
${ }^{14}$ If a common agricultural policy ever sees the light of day, what are the elements of this policy which, in relation to decision or management, will be delegated to European organisms?

${ }^{15}$ One of the most important factors of this transformation of national administrations, which has been alluded to earlier in this study, is the temporary employment of national officials in the higher posts of the European administration. National administrations, however, do not yet employ European officials,

${ }^{18}$ The European Communities do not have at their disposal any physical constraining force. In regard to the States, the powers of the Community are no stronger than in international relations. In regard to individuals, the Communities can exercise acts of constraint only through the intermediary of the national governments. (Decisions which impose financial obligations on enterprises or private persons are executory, and are to be enforced in each of the Member States through their legal procedure with no formality other than certification of the authenticity of such decisions. E.C.S.C. Treaty arts. 44, 92; E.E.C. Treaty art. I92.) The control and inspection functions which the Community authorities can exercise with regard to individuals (E.C.S.C. Treaty arts. 47,86 ) and sometimes even with regard to States (Euratom Treaty art. 8I) do not have provision for the use of physical constraint.
} 
munity law thus emerges as a real juridical system ${ }^{17}$ having complex relationships with national law. ${ }^{18}$

\section{A. Community Law as a Juridical System}

Every international organization develops, more or less extensively, its own law concerning its relations with its agents or officials, with those subject to its control (when it has direct powers of control), sometimes with its suppliers, and also sometimes with its Member States (this last category of relationships being more delicate and subject to controversy)..$^{19}$ This remark applies in an eminent degree to the European Communities, because they exercise direct powers of administration and control with respect to numerous and important enterprises and because the States have agreed to place themselves in a subordinate position to the Communities concerning numerous spheres of activity and concerning the most important State functions-the legislative and judicial functions.

Not surprisingly, controversies have arisen at the outset as to the characteristics of this Community Law. To some persons it would appear as pure administrative law developed from a Treaty which forms its base-the unique foundation of Community law. According to this view, such law would develop from the Treaty by virtue of whatever general legal principles are common to the national jurisprudences of the six Member States. In this perspective, international law, contemplated with the greatest reticence, is practically excluded from Community relationships; and the fear apparently is entertained that international law, because of the principles of coordination which are at its base, would not be conducive to the evolution of the Communities. ${ }^{20}$

For other persons, the relationships between States within the Communities, as well as those between the States and the organs of the Community, spring from international law. It goes without saying that in this case the thought is for protecting the independence of small or medium States, which feel themselves menaced more than the other members by the federal regime. The political objects associated with these different positions are evident. Indeed, this is only a more technical aspect of the quarrel about supranational institutions which has developed since r953 on the political scene of several countries-notably in France.

From the scientific point of view, the study of organizations such as the European Communities would show that, in reality, international law and internal law are not at all separated in so absolute a manner as certain German and Italian doctrines have tended to assert. As the Treaties which created the Communities have pro-

${ }^{17}$ See subsection $A$, infra.

${ }^{18}$ Sec subsection $B$, infre.

${ }^{10}$ Sec P. Reuter, International Institutrons 227 (1958).

${ }^{20}$ Although the Community Court of Justice aroids, as it should, taking any position in regard to this question, lawyers in general evidence a preoccupation with it in studies as well as in conclusions submitted to the Court. See, e.g., Lagrange, Juridical Order of E.C.S.C., REvuE DE DroIr Public 84I (1958); Conclusions of Roemer, in Case Nos. 24/58 and 34/58, Oct. 30, 1958, [x958] JoURNAI OfFICIEI 484 . 
vided in relation to the role of the Court of Justice, the international agreements which created the Communities are undoubtedly the principal source of Community law; ${ }^{21}$ but the Court can be called upon to apply the provisions of other Treaties and particularly the general rules of international law, in so far as there is no derogation from the basic agreements. ${ }^{22}$ Naturally the Court is called upon to apply the general principles of internal law-particularly on the basis of the national law of the six member countries. ${ }^{23}$ Thus, the existence of a Community juridical order of great richness is apparent. It comprises numerous juridical sources-e.g., treaties, custom, general principles of international law and of internal laws, numerous legislative or regulatory decisions emanating from the European Communities, as well as international agreements concluded by the latter with third-party States or other international organizations. It is impossible to deal here with the mass of problems presented by this variety of juridical sources; but two examples can be given that will show to what extent Community law brings into issue problems of federal technique. The first example will relate to the constitution of the Communities; the second, to their legislation.

In what sense and up to what point can it be said that the European Communities have a constitution? This problem is not specifically a Community one; it would arise in connection with other international organizations, notably those whose constitutive charters bear the title of "constitution," as in the case of the International Labor Organization. But the title or denomination of a juridical act is neither conclusive nor essential. It is quite clear that, from a formal point of view, the different agreements which have founded the European Communities are international treaties. At first sight, if one speaks of "constitution" in relation to those Communities, that term can only refer to the material character of those treaties. They would be constitutions in so far as they establish institutions and fix the fundamental and general rules that are to govern the relationships with which they are concerned.

In this sense, what would be the consequence of the constitutional characteristic of these treaties? It is not necessary to invoke this characteristic in order to force the Community organs or the Member States to respect the Treaties; this consequence results from their being treaties between States. However, recourse might be had to this characteristic to explain either certain problems of interpretation of the Treaties or certain peculiarities of their revision. It has already been pointed out that the interpretation of treaties creating international organizations is subject to special rules, notably as regards the implied authority of the organization. ${ }^{24}$ The revision of these treaties is in the same way subject to particular rules of practice paralleling

${ }^{21}$ E.C.S.C. Treaty art. 31 ; E.E.C. Treaty art. 164; Euratom Treaty art. 136.

${ }_{23}$ In the decree No. 8/55 of Nov. 29, 1956, 2 Recueil OfFicier DE JURISPRudence de LA Cour 305 (1956) [hereinafter cited as REC.], the Court applied "a general rule of interpretation admitted alike in international and national law."

${ }^{33}$ See Dec. Nos $7 / 56$ and $8 / 57,3$ Rec. 223 (1957). As to the general principles of law, see $P$. Reuter, INTERNATIONAL' PuB́lic LAW 87 (1958).

${ }^{24} \mathrm{C}$. de Visscher, Judicial Interpretation of Treaties of International Organizations, RIvisTA DI DIRITTO INTERNATIONALE 167 (1958). 
the rules applicable to the reservations which Member States can introduce when signifying their adherence. ${ }^{25}$ In this connection, if certain Community agreements were analyzed, notably those which have instituted the E.C.S.C. and Euratom, it would be evident that these agreements contain provisions of quite different juridical dignity and that the procedure for the revision of these agreements takes note of that fact. In fact, the E.C.S.C. Treaty has prescribed simplified procedures for revision, in which certain provisions of the Treaty are placed on a higher hierarchical level than that which relates to the ordinary articles. ${ }^{26}$ These privileged provisions are those which define the principles of the common market and the equilibrium of the institutions. Taking a contrary course, the Euratom Treaty has reduced to a lower class certain of its provisions-particularly those which contain technical rules -in order to permit an easier revision than for the other provisions of the Treaty. ${ }^{27}$

These observations, of whatever interest they may be, are still secondary. The Court of Justice has annulled a decision emanating from the executive organs of the Communities on the ground that it was contrary to the constitutional equilibrium of powers. ${ }^{28}$ However, in any case, the annulment of such a decision would have been decreed as a violation of the Treaty. A further step may be taken pursuant to the constitutional theory by contending that the agreements creating the European Communities have definitely become constitutions with regard to the Member States, so that these States have lost the power to modify the agreements by means of international treaties. If the revision clauses contained in these agreements are examined, it is seen that, in fact, all the revision procedures authorized there contain the obligation to bring the Community organs into action, at least for purposes of consultation. It is then arguable that the States can no longer modify these agreements by international treaties concluded in an entirely free manner, outside of the revision procedures laid down in the original agreements. In other words, the States would no longer be free to undo what they had done by using the same method or even by their unanimous agreement. Thus, they would have delegated a part, small but certain, of their treaty-making power. Such is the thesis finally accepted by the Netherland Parliament (although initially the Dutch government had taken the contrary position) under political pressure from an eminent protagonist of European unity, Mr. van der Goes van Naters. ${ }^{29}$ Here one is at the threshold of federalism in the strict sense; but the point of view just outlined is probably not that of all the governments. Against it the adversaries of European unification would argue once again - as they did concerning the Defense Community in 1954that the Treaties setting up the European Communities are unconstitutional according to internal law.

${ }^{5}$ Cf. E. C. Hoyt, The Unanimity Rule in the Revision of Treaties-A Re-examination (1959).

${ }^{20}$ E.C.S.C. Treaty art. 95.

${ }^{27}$ Euratom Treaty arts. 92, 197, 215, 76, 85, 90.

${ }^{28}$ Meroni v. Haute Autorité, Dec. Nos. 9-10/56, June 13, 1958, 4 Rec. 36 (1958).

${ }^{20}$ See Reuter, The Revision of Supranational Treaties, NederLands Tijpschrift voor Internatronaal RECHT 120 (1959). The E.C.S.C. Treaty has, in fact, been modified outside of the procedures laid down on Oct. 27, 1956, as to a point of detail connected with the settlement of the Saar question. 
The practice on points of detail often stresses the constitutional nature of the agreements creating the Communities. Thus, to cite a recent example, the Treaty setting up the E.C.S.C. was recently modified under the special procedure provided in the last paragraph of article ninety-five. According to classical treaty technique, notice of this modification should have been given to the French government, the depositary of the Treaty, which would have informed the Member States. Instead, following a technique more federal than international, the text of the modification was published in the Journal Officiel of the European Communities ${ }^{30}$-the Council of Ministers confining its action to notifying the Member States, so that they could take all measures eventually required according to their internal law.

The second example to be brielly cited relates to Community legislation. The Communities can establish, under different titles, general rules which are binding not only on governments but directly on individuals. In the case of the E.C.S.C., this power is limited to certain rather technical measures, and has been regarded by certain writers as a secondary legislative or rule-making power. In the E.E.C., the power has been considerably extended, and so its legislative character is even more striking. In fact, as has been pointed out several times, the E.E.C. Treaty contains only general principles, general directives; real Community laws are necessary to make the execution of the Treaty possible. As the texts of these Community laws can relate to matters which in the member countries are regulated by national laws, the importance of the powers of this Community can easily be assessed.

Numerous problems arise in connection with this legislative power, the most frequent form of which in the E.E.C. is that of regulations adopted by the Council of Ministers. In certain instances these regulations are based on a proposal by the Commission-sometimes with the advice of the Assembly. In other cases, they are decided upon by the Council alone; and the Council in some cases must come to a unanimous decision.

The decisions of the Council passed on a unanimous vote cannot fail to give rise to numerous reflections. In fact, the difference between an internal convention signed by the representatives of the six countries and a unanimous decision of the Council of Ministers is, at the same time, very superficial and very wide. It is superficial because in both cases the national States indicate their consent; and it is wide because the decision of the Council is valid in its own right and will receive its full application by publication in the Journal Officiel of the European Communities, but a convention will be subject to all the other procedures laid down by the national constitutions, including national parliamentary sanction. In this sense, it can be said that the creation of the Communities, and particularly that of the E.E.C. (founded on a Treaty which is a mere framework), results in a lessening of the powers of the national parliaments, rather than of the national governments.

\footnotetext{
This is the case of a veritable promulgation (not laid down by the Treaty) effected jointly by the President of the Council of Ministers and the President of the High Authority on May 16, 1960, [1960] JoURNAL OFFICIEL $78 \mathrm{r}$.
} 
These two juridical categories-the Convention of the Six and the decision of the Council-are so similar to each other that, in practice, they are sometimes confused. Many of the articles of the Treaties founding the Communities are not precise, and the question arises: Do they refer to one or the other of these procedures? One single example will be cited-that of article 235, which, in the case of gaps in the Treaty, authorizes the Council, acting by unanimous vote, to take the appropriate measures. The Treaty texts are often ambiguous; and by virtue of this mechanism, the six governments have been able to avoid recourse to the conventional international procedure. ${ }^{31}$ They may be tempted to do so again in less certain circumstances. ${ }^{32}$ Indeed, it is the evolution of the European political forces which will determine what use can be made of so sweeping a power conferred upon six governmental delegates.

B. Relations between Community Law and National Laws

Just as in an authentic federal system, the relations between Community law and national laws are very complex-even apart from the phenomenon noted above that the common general principles of the several systems of national law are themselves a source of Community law. To illustrate the complexity of the relations between Community law and the extensive domain which, to varying degrees, is allotted to national laws, it will be well to observe the framework of the E.C.S.C. A certain number of matters-restrictively defined by the Treaty-have been transferred to the Community, sometimes with a reservation of concurrent jurisdiction for national laws. Other matters have rested within the primary jurisdiction of the Member States and their national laws. In some cases the States have obligated themselves to exercise their jurisdiction in accord with rules laid down by the Treaty; in other cases, to harmonize their exercise of jurisdiction with the aims of the Treaty; and in the majority of cases, the States have undertaken no obligations as to the exercise of their jurisdiction. A greater uncertainty prevails in the case of the E.E.C. because-it must be repeated once again-the Treaty establishing this Community is a skeletal agreement which provides no choice between direct and indirect administration. Without fear of being disproved by future event, the forecast can be made that, for the greater part, the powers of the Member States will not be transferred to the Communities. Instead, the Communities will fashion rules and limit their functions to the supervision of the applications of these rules, with the assistance of the Court of Justice-while, by methods varying from multilateral convention to parallel legislation, the Member States will seek to harmonize their national laws dealing with a wide variety of activities.

Even with reduced intervention by the Communities, the relations between Community law and national laws call for adjustments. How are the national States

"E.E.C. Regulation No. 3, [1958] Jouraral Officiel 56r, has authorized the bringing into force, without ratification, of the contents of an earlier International Convention of Dec. 9, r957, signed at Rome.

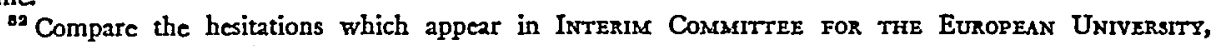
REPORT (April 27, I960). 
going to make room in their juridical order for Community regulations and decisions? This is a very difficult question which should be examined separately with respect to each country. Cases can well be imagined where it will be a delicate matter to make Community regulations supersede the national laws, to which, however, they are superior in the hierarchy of legal authority.

The relations between the Community Court of Justice and the national tribunals cannot by their interaction alone resolve all these difficulties; nevertheless they have a great importance for the establishment of harmonious relations between the Community juridical system and the national ones. In this regard, it must be pointed out that generally the tribunals of the Member States do not depend on the Court of Justice of the European Communities for their authority or look to it for their control; and they even may be said to avoid any control by this Court. Furthermore, the power of the Court of Justice is limited quite precisely and is far from extending to all matters where a violation of Community law is alleged. For example, if a State or an individual violates Community law, another individual who is aggrieved must normally resort to the national tribunals. ${ }^{33}$ The Treaties contain certain indispensable rules for adjusting jurisdictional relations. The Court of Justice of the European Communities has considered itself competent to apply the national law of one of the States each time that the Treaty stipulates a renvoi to that law-as, for example, in matters concerning personal capacity and status ${ }^{34}$-although it does not consider itself competent to decide a suit whose principal object pertains to national law..$^{35}$ Conversely, the national tribunals may find themselves called upon to interpret or assess the regularity of Community rules or decisions. The E.C.S.C. Treaty has forbidden national tribunals to assess the validity of the acts of the High Authority and the Council, and obliges these tribunals to certify this question as a preliminary one to the Court of Justice. ${ }^{36}$ Similarly, the High Authority has exclusive authority, subject to appeal to the Court of Justice, to rule upon the validity of agreements contrary to the rules of the Treaty relating to cartels. ${ }^{37}$ These adjustments are still insufficient and have not operated satisfactorily. ${ }^{38}$ The problem has been considered in a more systematic way by the E.E.C. Treaty ${ }^{30}$ and the Euratom Treaty, ${ }^{40}$ which read as follows:

\footnotetext{
${ }^{83}$ The individual can first submit a claim to the Community executive and if that body refuscs to take the measures necessary to put an end to the trouble, he can start an action protesting this refusal before the Court (this procedure is known as "in carence"). E.C.S.C. Treaty art. 35; E.E.C. Treaty art. 175 .

${ }^{84}$ See Nold v. Haute Autorité, Dec. No. 18/57, March 20, 1959, 5 Rec. 89 (1958-59), and alsoalthough more clearly expressed in the conclusion of the Avocat Général than in the decree-Mannesman A.G. et al., Dec. of April 4, 1960, Joint Affairs 13/59.

${ }^{85}$ Case No. $1 / 58$, Friedrich Storck \& Cie.

${ }^{38}$ E.C.S.C. Treaty art. $4 \mathrm{I}$.

${ }^{37}$ Id. art. 65 .

${ }^{38} \mathrm{Cf}$. case No. $1 / 58$ cited above, as well as the cases of $\mathrm{OKU}$ before the Stuttgart Tribunal (judgment of Aug. 10, I953), or the interminable case of Saarbergwerke (decree of the Bundesgerichts of April 14, r959, 14 Betriebs-Berater 576.78 (1959)).

${ }^{30}$ E.E.G. Treaty art. 177 .

${ }^{40}$ Euratom Treaty art. I5O.
} 
The Court of Justice shall be competent to make a preliminary decision concerning=

(a) the interpretation of this Treaty;

(b) the validity and interpretation of acts of institutions of the Community; and

(c) the interpretation of the statutes of any bodies set up by an act of the Council, where such statutes so provide.

Where any such question is raised before a court or tribunal of one of the Member States, such court or tribunal may, if it considers that its judgment depends on a preliminary decision of this question, request the Court of Justice to give a ruling thereon.

Where any such question is raised in a case pending before a domestic court or tribunal from whose decision no appeal lies under municipal law, such court or tribunal shall refer the matter to the Court of Justice.

This provision is more logical and more complete than the scattered provisions. of the E.C.S.C. Treaty. In order to produce its effects, it presupposes a certain submission on the part of the national tribunals. In fact, these tribunals can always consider that the text of the provision in issue is clear and has a definite meaning, in which case they are not obliged to refuse jurisdiction. This seems to have been the attitude of several national tribunals in certain matters that they already have: confronted.

These brief comments show clearly that the relations between the Community law and the national law are not yet completely harmonized, as they would be in a perfected federal system; but they also indicate better than a long commentary that these juridical relations have already reached a degree of complexity and of intimacy which vividly distinguishes them from traditional international relations. The Communities are not at all a federation; but they are progressing in that direction-more so by reason of their institutions than by the play of political forces, and likewise more so by their internal dynamic strength than by virtue of external factors. 